\title{
Vlastnosti uměle generovaných srážek využívaných pro studium eroze půdy
}

\section{MARTIN NEUMANN, DAVID ZUMR, PETR KAVKA, TOMÁŠ LABURDA, LISBETH LOLK JOHANNSEN, NIVES ZAMBON, TOMÁŠ DOSTÁL, PETER STRAUSS, ANDREAS KLIK}

Klíčová slova: disdrometr - kinetická energie deště - intenzita deště - deštový simulátor - eroze půdy

\section{SOUHRN}

Vodní eroze půdy se běžně studuje v laboratořích, experimenty bývají založeny na uměle generovaných srážkách s využitím deštových simulátorů. Typicky je vyhodnocován vliv různých faktorů, jako jsou intenzita nebo úhrn srážky, půdní charakteristiky, zpracování půdy, posklizňové zbytky nebo sklon a délka erozní plochy na erozi. Výsledky experimentů slouží pro lepší pochopení erozních procesů, odhad transportovaného sedimentu $\vee$ krajině nebo kalibraci matematických simulačních modelů. Vzhledem k tomu, že eroze je iniciována deštovou srážkou, je pro přenositelnost výsledků z laboratoře do krajiny zásadní, aby se simulovaná srážka co nejvíce bližila charakteristikám prírodních srážek. Intenzita deště se kontroluje poměrně snadno, ale klíčový dopad na erozní procesy má kinetická energie deště. Cílem tohoto přispěvku je komplexní vyhodnocení charakteristik simulovaného deště a porovnání jeho kinetické energie s energií prírodních srážek. Součástí výsledků je i porovnání několika běžně využívaných disdrometrů a diskuse využitelnosti disdrometrů pro charakterizaci simulovaných srážek.

Experiment byl proveden na laboratorním deštovém simulátoru Fakulty stavební ČVUT v Praze. Kinetická energie deště o různých intenzitách byla monitorována pomocí disdrometrů LPM (Thies Clima), Parsivel (OTT) a PWS100 (Campbell Sci.), za referenční údaj intenzity srážky byla považována data z překlopného srážkoměru MR3 (Meteoservis). Intenzitu deště měří všechny testované disdrometry uspokojivě. Přístroje naměřily 106 \% (LPM), 79 \% (Parsivel) a 116 \% (PWS100) hodnoty naměřené pomocí překlopného srážkoměru. V př́padě měření kinetické energie nebyla nastavena žádná referenční hodnota, ale přístroje byly porovnávány mezi sebou. LPM oproti ostatním dvěma přístrojům měři výrazně nižší kinetickou energii, jím naměřené hodnoty odpovídají v prưměru 83 \% hodnot naměřených Parsivelem, resp. 59 \% hodnot naměřených PWS100. Nejvyšší hodnoty kinetické energie měřil PWS100. Klíčovým závěrem je, že přivalová srážka simulovaná laboratorním deštovým simulátorem má znatelně nižší kinetickou energii než prírodní srážky o shodných intenzitách.

\section{ÚVOD}

Úhrn, doba trvání, intenzita, prípadně časový průběh jsou běžně monitorované parametry deštových srážek. Nicméně pro mnoho vědecky i prakticky orientovaných studií jsou podstatné i další charakteristiky srážek. Např́iklad pro studium eroze půdy je kličová kinetická energie dopadajících kapek, která rozhoduje o míre degradace půdních agregátů a prvotní mobilizaci půdních částic. Dalšími obory, pro které je účelné sledovat srážky podrobněji, jsou dálkový průzkum země, telekomunikace (útlum mikrovlnných spojů), radarová meteorologie, městská odvodnění (větší kapky s vyšší kinetickou energií snadněji uvolňují z chodníků a střech polutanty, které mohou být dále transportovány do vodních recipientů nebo ČOV) a další [1].

Pro experimentální výzkum erozních procesů se často využívají uměle generované srážky s využitím laboratorních nebo terénních deštových simulátorů. Cílem zadeštovacích experimentů je simulovat takový déšt', který má srovnatelné charakteristiky s prírozenou deštovou srážkou. Obvykle je kontrolována intenzita deště, trvání deště (celkový srážkový úhrn), případně prostorová a časová rovnoměrnost postřiku. Je známý fakt, že trysky vytváří odlišné spektrum velikostí kapek, než má prírodní déšt' [2], kapky z deštových simulátorů jsou obvykle menší. Vzhledem ke konstrukci většiny terénních i laboratorních simulátorů zpravidla kapky nedosahují terminální pádové rychlosti odpovídající prírodnímu dešti. Uměle generovaný déšť má proto typicky nižší kinetickou energii než prírodní srážka se stejnou intenzitou a dobou trvání, a nutně tak vyvolává jiný erozní účinek [3,4]. Kinetická energie uměle generovaného deště, která má fundamentální vliv na iniciační fázi eroze půdy, běžně během experimentů měřena není.

Typicky požadovanými parametry srážek jsou rozlišení hydrometeorů (déšt', sníh, kroupy, mlha atd.), distribuce velikostí a rychlostí kapek, kinetická energie deště nebo viditelnost. Většinu zmíněných parametrů Ize pozorovat, měřit, prípadně vypočítat i bez složitého technického vybavení. Např́klad distribuce velikostí kapek se historicky určovala pomocí testů s moukou [5], kdy byla po dopadu kapek do mouky manuálně měřena plocha jejich otisku. Obdobně bývaly deštové kapky zachytávány do misky s olejem o specifické viskozitě a opět manuálně analyzovány. Díky své jednoduchosti je pro určité aplikace tato metoda občas využívána, byt v mírně modifikované formě, i v současnosti [6]. Pro analýzu delších časových řad a monitorování srážek v reálném čase však nejsou tyto metody vhodné.

Relativně moderní, byt už poměrně rozšîrenou, technologií pro automatizované a komplexní monitorování srážek jsou disdrometry. Většinou se jedná o soběstačná bezúdržbová zařizení s kontinuálním záznamem počtu, efektivního průměru a pádové rychlosti jednotlivých frakcí deštových kapek. Nejčastěji využívané disdrometry Ize dělit podle principu měření na tři základní typy [7]: (i) elektromechanické disdrometry, které př́mo měři kinetickou energii dopadajících kapek na podložku (měřeny jsou mechanické vibrace nebo akustická odezva); (ii) video disdrometry (1D nebo 2D), které pomocí vysokorychlostního CCD snímače zaznamenávají tvar a počet kapek, z čehož lze vypočíst efektivní průměr, pádovou rychlost, kinetickou energii i úhel dopadu deštové kapky [8]; (iii) optické (typicky laserové) disdrometry, které měří útlum intenzity svazku rovnoběžných laserových paprsků vlivem propadávajících kapek. Na základě útlumu lze vypočítat počet, velikost a pádovou rychlost kapek. 

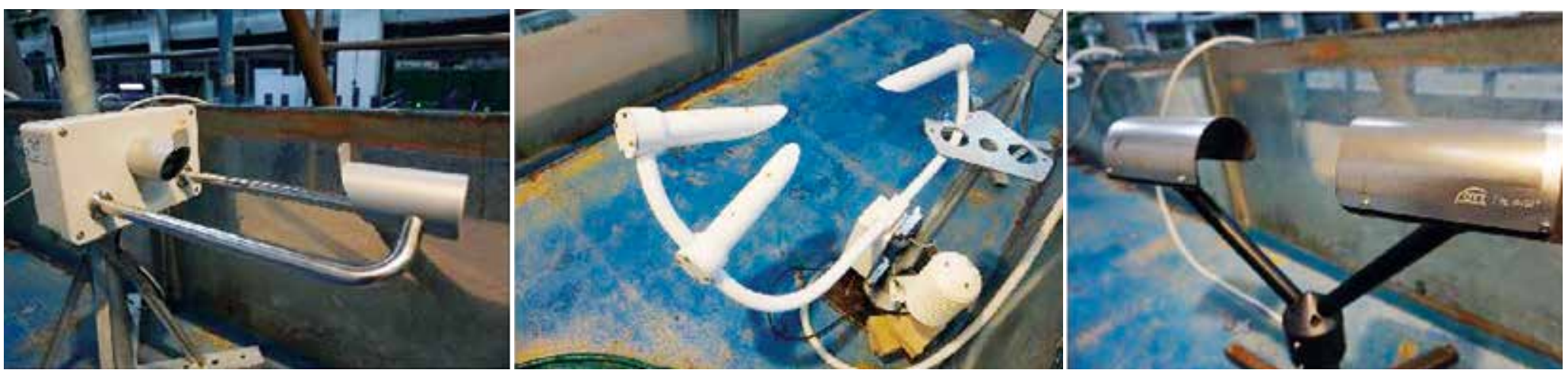

Obr. 1. Disdrometry zleva: Thies LPM, PWS100, Parsivel

Fig. 1. Tested disdrometers (from left): Thies LPM, PWS100, Parsivel

Laserové disdrometry jsou schopny pracovat po dlouhou dobu téměř bez obsluhy, výstupní data Ize zpracovávat téměř v reálném čase. Oproti překlopným srážkoměrům nevyžadují časté čištění ani kalibraci, což je předurčuje i pro monitorování intenzity deště. To, spolu s relativní finanční dostupností a spolehlivostí, laserové disdrometry předurčuje k masovému využívání nejen $\checkmark$ meteorologii.

$\checkmark$ literatuře Ize dohledat výsledky experimentů a terénních monitorování, které mají za cíl porovnat disdrometry a standardizované metody na bázi překlopných srážkoměrů. Např́klad porovnání elektromechanického disdrometru, radaru a optického disdrometru prováděli Sarkar a kol. [9]. Spolehlivost disdrometrů s ohledem na stanovení intenzity deště testovali Nakaya a kol. [10], Lanzinger a kol. [11], Martinez a kol. [12], typy srážek stanovovali Hannelore a kol. [13]. Pro výzkum a modelování eroze půdy je zásadní informace o kinetické energii kapek a její funkční závislosti na intenzitě deště. Přehled publikovaných vztahů mezi intenzitou prirozeného deště a kinetickou energií, odvozených s využitím disdrometrů, shrnuje Angulo-Martínez a kol. [14]. Vzhledem k dostupnosti disdrometrů pribývá literatury s podrobnými charakteristikami různých typů srážek, začínají být testovány i charakteristiky uměle generovaných srážek. Avšak komparativní studie výstupů disdrometrů od různých výrobců při monitorování přirozených srážek ukazuje systematicky odlišné výsledky [12]. To je dáno jak různým principem měření, tak rozdíly v konstrukčních a technologických detailech jednotlivých disdrometrů, jako jsou napřr. rozdílné detektory intenzity záření, různé vlnové délky laserových paprsků, různé úhly mezi detektory rozptýleného záření nebo jiný systém klasifikace velikosti kapek. Variabilita měřených charakteristik deště byla zjištěna dokonce i při použití stejného typu přístroje, jak ukazuje na srovnání pěti disdrometrů Thies LPM Frasson a kol. [15] nebo dvou disdrometrů PWS100 [16].

Ukazuje se, že během simulovaných srážek jsou často generovány kapky mimo detekční limity některých disdrometrů (malé kapky s vysokou rychlostí), různé prrístroje tak měří různou kinetickou energii. Srovnávací studie, která by vyhodnocovala variabilitu měřených charakteristik simulovaných deštů s využitím různých typů disdrometrů, dosud chybí. Cílem tohoto príspěvku je porovnání tři typů nejčastěji používaných optických laserových disdrometrů v podmínkách uměle generovaného deště. Druhým cílem příspěvku je porovnání měřené kinetické energie simulovaných srážek s vypočítanou kinetickou energií prírodních srážek.

\section{METODIKA}

V laboratorních podmínkách jsme uskutečnili sérii pokusů s uměle generovaným deštěm o různých intenzitách a opakovaně jsme měřili jeho charakteristiky pomocí tř́i, v praxi běžně používaných, disdrometrů. Výsledky měřené pomocí disdrometrů a referenčního překlopného srážkoměru jsme porovnali. Charakteristika simulovaného deště byla následně porovnána s teoretickými parametry prírodní srážky o shodné intenzitě. Kinetická energie přirozeného deště byla vypočítána podle v literatuře publikovaných vztahů.

\section{MONITOROVÁNÍ CHARAKTERISTIK SIMULOVANÉHO DEŠTĚ}

Pro monitorování charakteristik deště byly využity tři disdrometry, jako referenční měření byla intenzita deště měřena člunkovým překlopným srážkoměrem (měrná plocha $500 \mathrm{~cm}^{2}$, rozlišení $0,1 \mathrm{~mm}$ ). Všechny disdrometry jsou optické, laserového typu, měří a zaznamenávají efektivní průměr a pádovou rychlost deštových kapek. Kapky jsou automaticky klasifikovány do několika velikostních a rychlostních tříd. Jednotlivé disdrometry (LPM Thies Clima, PWS100 Campbell Sci., Parsivel OTT) se od sebe liší vInovou délkou laseru, měrnou plochou, rozsahem měřitelných velikostí a rychlostí kapek, počtem velikostních a rychlostních tříd (tj. rozlišením histogramů). Na obr. 1 jsou použité disdrometry znázorněny.

\section{LPM - (LASER PRECIPITATION MONITOR)}

Disdrometr Thies LPM je vyráběn v Německu firmou Thies Clima, konkrétní přístroj je distribuován pod označením 5.4110.10.000. Tento disdrometr je velmi často využíván zejména při monitorování laboratorních experimentů a ve výzkumu erozních procesů [17]. Důvody jeho častého využívaní jsou relativně malá velikost, jednoduchost použití a interpretace výsledků a výrazně nižší pořizovací cena oproti ostatním disdrometrům.

Thies LPM využívá infračervený paralelní světelný paprsek o vlnové délce 786 nm, měřená plocha užitého přístroje je 44,1 cm². Přesná velikost měrné plochy se pro konkrétní přístroje liší a musí být upravena pomocí korekčního koeficientu od výrobce pro daný výrobek. Opomenutí korekce vede k chybné charakterizaci deště [15]. Rozsah měřitelných průměrů kapek je 0,16-8 mm a pádových rychlostí 0,2-20 m.s.-1. Podle velikosti jsou kapky tríděny do 34 kategorií, podle pádové rychlosti do 34 kategorií (1 156 kombinací průměru a rychlosti kapky). Rozsah měřtelné intenzity srážky udávaný výrobcem je 0,001-250 mm.h-1. Vnitřní algoritmus disdrometru rozeznává typ srážky (vodní kapky, sníh, kroupy, mlha) [13]. Součástí disdrometru je software Thies LNM View, v jehož prostředí Ize sledovat měřené veličiny, vizualizovat distribuční funkce velikostí a rychlostí kapek a vypočítat další parametry srážky (intenzita, průměrná velikost kapek, průměrná rychlost kapek, kinetická energie deště). 


\section{PWS100 - (PRESENT WEATHER SENSOR)}

PWS100 je distribuován firmou Campbell Scientific (Velká Británie), standardně jako součást velkých meteorologických stanic. Optický disdrometr využivá paprsek v IR spektru o vinové délce $830 \mathrm{~nm}$, měřená oblast je $40 \mathrm{~cm}^{2}$. Rozsah měřitelných průměrů kapek je 0,1-30 mm a pádových rychlostí 0,16-30 m.s.1. Podle velikosti jsou kapky trí́děny do 22 kategorií, podle pádové rychlosti do 20 kategorií (440 kombinací průměru a rychlosti kapky). Rozsah měřitelné intenzity srážky udávaná výrobcem je 0-999,9 mm.h-1 s rozlišením 0,0001 mm. Data z disdrometru jsou zaznamenávána dataloggerem a ukládána na SD kartu.

\section{PARSIVEL}

Parsivel je vyráběn společností OTT (Německo). V současnosti je v distribuci už druhá generace disdrometru pod označením Parsivel ${ }^{2}$, která má mírně odlišné charakteristiky a $\vee$ rámci této studie nebyla testována. Parsivel první generace využívá paprsek o vinové délce $650 \mathrm{~nm}$, monitorovaná plocha je $54 \mathrm{~cm}^{2}$ $(180 \times 30 \mathrm{~mm})$. Rozsah měřitelných průměrů kapek je 0,2-5 mm (pevné částice do $25 \mathrm{~mm}$ ) a pádových rychlostí 0,2-20 m.s. Podle velikosti jsou kapky tríděny do 32 kategorií, podle pádové rychlosti do 30 kategorií (1 024 kombinací průměru a rychlosti kapky). Rozsah měřitelné intenzity srážky udávaná výrobcem je 0,001-1 $200 \mathrm{~mm} \cdot \mathrm{h}^{-1}$. Obdobně jako Thies LPM byl Parsivel připojen k PC se spuštěným programem pro záznam a vyhodnocení charakteristik deště.

\section{SIMULACE DEŠTĚ}

Pro simulaci srážky byl použit laboratorní tryskový deštový simulátor typu Norton Ladder, umístěný ve vodohospodářské laboratoři Fakulty stavební ČVUT v Praze [18]. Simulátor je osazen osmi kyvnými tryskami Veejet 80100 ve dvou řadách, které pracují při vodním tlaku 41 kPa [19]. Trysky jsou neustále otevřené, intenzita deště na ploše pod tryskami je regulována nastavením frekvence kyvů trysek a délkou prodlevy mezi jednotlivými kyvy. Pádová výška kapek je 2,6 m, simulátor je vhodný pro použití při intenzitě 20-80 mm.h $h^{-1}$. Běžně uživaná experimentální plocha pro zadeštování má rozměr $1 \times 4$ m, teoreticky lze využít prostor o rozměrech približně $1,5 \times 6 \mathrm{~m}$.

Pro testování disdrometrů jsme využili skutečnosti, že rozložení intenzity srážky není v ploše pod tryskami simulátoru zcela rovnoměrné, na okrajích experimentální plochy má déšt nižší intenzitu, prímo pod tryskami vysokou intenzitu. Pod deštovým simulátorem bylo vytipováno osm pozic s rozdílnou intenzitou simulovaného deště $\vee$ rozmezí cca 20-80 mm.h-1 (obr. 2). Na tyto pozice byly $v$ průběhu simulované srážky opakovaně umistovány testované disdrometry a srážkoměr tak, že vždy geometrický střed měrné oblasti konkrétního disdrometru byl nad stejným bodem. Disdrometry byly orientovány rovnoběžně s hlavním ramenem deštového simulátoru. Mimo disdrometry a srážkoměru byly pro kontrolu na vytipovaných pozicích rozmístěny odměrné nádoby s definovanou sběrnou plochou (srážkový totalizátor).

Přemistování jednotlivých disdrometrů a srážkoměru mezi vytipovanými pozicemi bylo prováděno bez přerušování simulace deště, aby nedocházelo k tlakovým rázům v systému simulátoru, a tak kolísání intenzity srážky. Všechny př́stroje zaznamenávaly údaje $v$ minutovém kroku, na každé pozici byly umístěny 30 minut. Pro vyhodnocení bylo využito monitorování ze středních 24 minut.

Kinetickou energii deště Ize vztahovat na určitý časový úsek $K_{R}\left(J \cdot m^{-2} \cdot h^{-1}\right)$, nebo na určitý srážkový úhrn KE $\left(J \cdot \mathrm{m}^{-2} \cdot \mathrm{mm}^{-1}\right)$. První prípad obecně charakterizuje kinetickou energii konkrétní srážkové události, která mohla mít v čase proměnlivou intenzitu. Druhý př́pad charakterizuje typ srážky. Literatura uvádí (např. [20]), že samotná intenzita deště nemusí mít významný vliv na distribuci
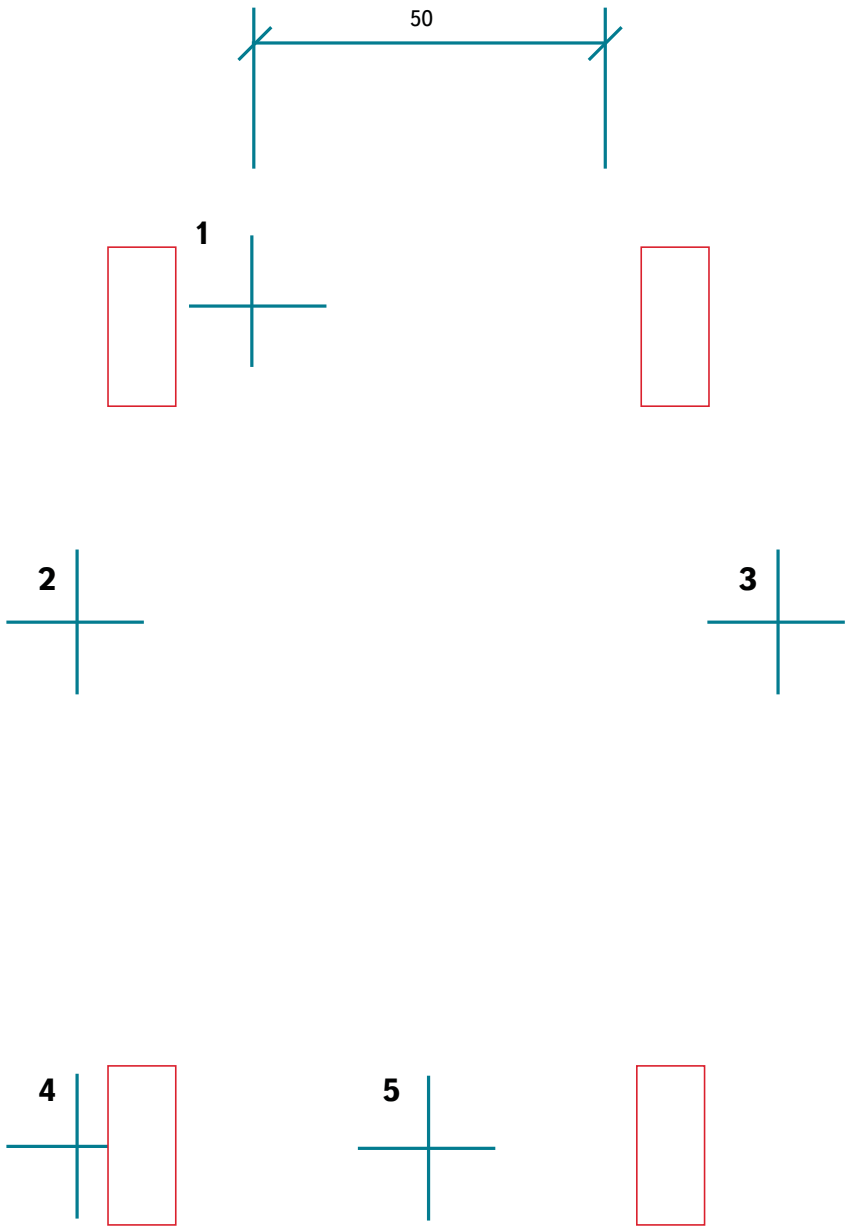

น
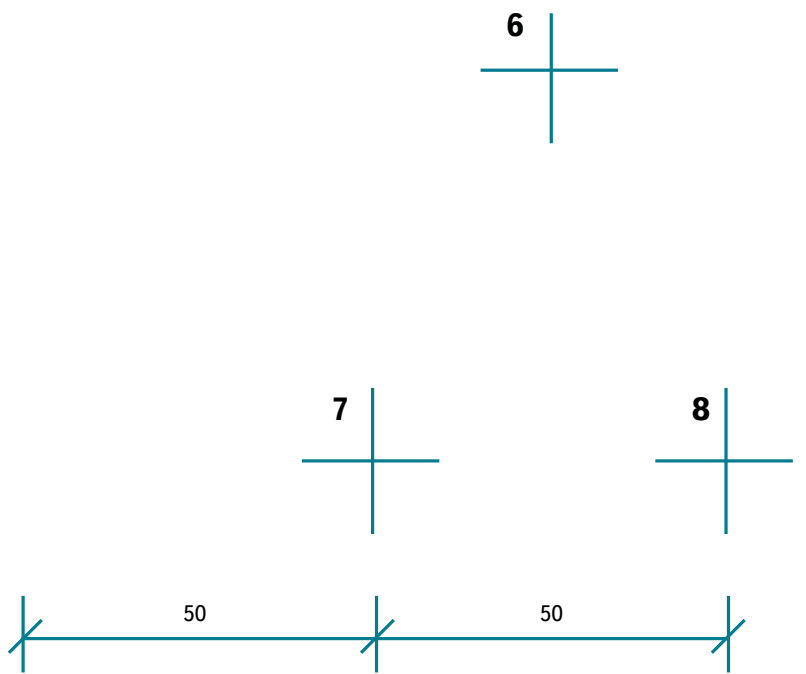

Obr. 2. Rozložení disdrometrů s číselným označením pozice, červeně je naznačena pozice trysek

Fig. 2. The tested positions under the rainfall simulator, red rectangles represent the nozzles 
velikostí kapek. Avšak distribuce velikostí kapek je odlišná pro různý typ nebo lokalitu srážky (např. konvektivní vs. stratiformní, nebo kontinentální vs. př́imořská oblast). Pro porovnání disdrometrů jsme použili oba způsoby vyjádření kinetické energie.

Intenzita srážky a kinetická energie srážky pro každý minutový úsek byla vypočítána z měřené distribuce kapek a jejich rychlostí podle vztahů:

$$
\begin{aligned}
& I=\left(\frac{\pi}{6}\right)\left(\frac{3,6}{10^{3}}\right)\left(\frac{1}{A t}\right) \sum_{i=1}^{x} n_{i} D_{i}^{3} \\
& K E_{R}=\left(\frac{\pi}{12}\right)\left(\frac{1}{10^{6}}\right)\left(\frac{3600}{t}\right)\left(\frac{1}{A}\right) \sum_{i=1}^{x} n_{i} D_{i}^{3} V_{D, i} \\
& K E=\frac{K E_{R}}{1}
\end{aligned}
$$

kde I je intenzita srážky $\left(m m \cdot h^{-1}\right)$,

A měrná plocha laserového paprsku disdrometru $\left(\mathrm{m}^{2}\right)$,

t doba sběru dat (s),

KE kinetická energie $\left(J \cdot m^{2} \cdot h^{-1}\right)$,

$K E_{\mathrm{R}} \quad$ kinetická energie $\left(J \cdot \mathrm{m}^{2} \cdot \mathrm{h}^{-1}\right)$,

$N$ počet kapek $v$ kategorii (-),

D průměr kapky $(\mathrm{mm})$,

$V_{D} \quad$ rychlost kapky o průměru $D\left(m \cdot s^{-1}\right)$

\section{VÝSLEDKY}

Průměrné hodnoty intenzity a kinetické energie na jednotlivých pozicích jsou uvedeny $v$ tabulce 1 a znázorněny na obr. 4. Jde vždy o průměr z trojice osmi minutových intervalů (celkem 24 hodnot) měřených pomocí jednotlivých disdrometrů.

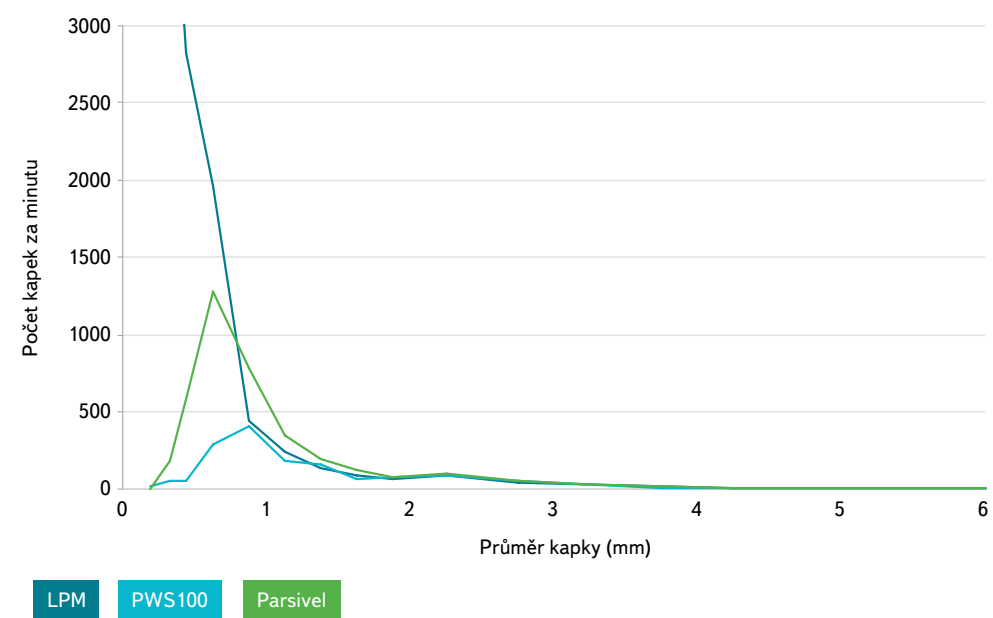

Obr. 3. Distribuce velikosti kapek při intenzitě $62 \mathrm{~mm} \cdot \mathrm{h}^{-1}$ zaznamenané jednotlivými disdrometry

Fig. 3. Drop size distribution at the rainfall intensity of $62 \mathrm{~mm} \cdot \mathrm{h}^{-1}$ as recorded by different disdrometers

Jak bylo uvedeno, kinetická energie je dopočitávána z informací o množství a velikosti deštových kapek. Z obr. 3 je patrné, že disdrometry detekují různé počty kapek, a to predevším těch malých. Thies LPM zaznamenává pro malé kategorie mnohem více kapek, než oba ostatní disdrometry. Pro kapky s efektivním průměrem pod 0,5 mm dokonce minutová množství přesahují 5000 mikrokapek. Pro hodnoty nad $1 \mathrm{~mm}$ jsou již počty kapek pro všechny disdrometry obdobné. Mírné rozdíly lze očekávat, protože každý disdrometr má jinou průletovou plochu a jinak uspořádané velikostní třídy. Avšak v relativním měřítku by distribuční funkce měly vypadat podobně.

Disdrometry se v praxi využívají zejména na monitorování intenzity deště. Z porovnání měření disdrometrů a srážkoměru na pozicích s různou intenzitou deště plyne, že testované přístroje udávají srovnatelné výsledky. Přístroje naměřily 106 \% (LPM), 78 \% (Parsivel) a $116 \%$ (PWS100), hodnoty naměěené pomocí překlopného srážkoměru. $V$ prípadě měření kinetické energie nebyla nastavena žádná referenční hodnota, ale přístroje byly porovnávány mezi sebou.

Tabulka 1. Prümërné hodnoty pro jednotlivé disdrometry na testovaných pozicich

Table 1. Average values of the kinetic energy and rainfall intensity recorded at the tested positions

LPM

Parsivel

\begin{tabular}{|c|c|c|c|c|c|c|c|c|c|c|}
\hline Pozice & Ekin & Ekin & Intenzita & Ekin & Ekin & Intenzita & Ekin & Ekin & Intenzita & Intenzita \\
\hline & $\left(J \cdot m^{-2} \cdot h^{-1}\right)$ & $\left(\mathrm{J} \cdot \mathrm{m}^{-2} \cdot \mathrm{mm}^{-1}\right)$ & $\left(\mathrm{mm} \cdot \mathrm{h}^{-1}\right)$ & $\left(J \cdot m^{-2} \cdot h^{-1}\right)$ & $\left(\mathrm{J} \cdot \mathrm{m}^{-2} \cdot \mathrm{mm}^{-1}\right)$ & $\left(\mathrm{mm} \cdot \mathrm{h}^{-1}\right)$ & $\left(J \cdot m^{-2} \cdot h^{-1}\right)$ & $\left(\mathrm{J} \cdot \mathrm{m}^{-2} \cdot \mathrm{mm}^{-1}\right)$ & $\left(\mathrm{mm} \cdot \mathrm{h}^{-1}\right)$ & $\left(\mathrm{mm} \cdot \mathrm{h}^{-1}\right)$ \\
\hline 1 & 715 & 7,7 & 92 & 1247 & 19,7 & 66 & 1220 & 17,3 & 71 & \\
\hline 2 & 804 & 11,3 & 71 & 1107 & 17,8 & 62 & 1298 & 17,5 & 74 & 69 \\
\hline 3 & 451 & 9,6 & 47 & 649 & 16,6 & 40 & 833 & 16,3 & 51 & \\
\hline 4 & 747 & 10,6 & 70 & 1073 & 21,7 & 51 & 1586 & 18,0 & 90 & \\
\hline 5 & 1171 & 13,9 & 85 & 1047 & 18,9 & 55 & 1651 & 20,0 & 82 & 78 \\
\hline 6 & 630 & 13,2 & 48 & 742 & 21,0 & 35 & 891 & 19,3 & 46 & 50 \\
\hline 7 & 398 & 12,7 & 31 & 388 & 16,7 & 23 & 871 & 20,2 & 43 & 27 \\
\hline 8 & 293 & 13,2 & 22 & 297 & 15,8 & 19 & 441 & 18,5 & 24 & \\
\hline
\end{tabular}

PWS100

Srážkoměr 

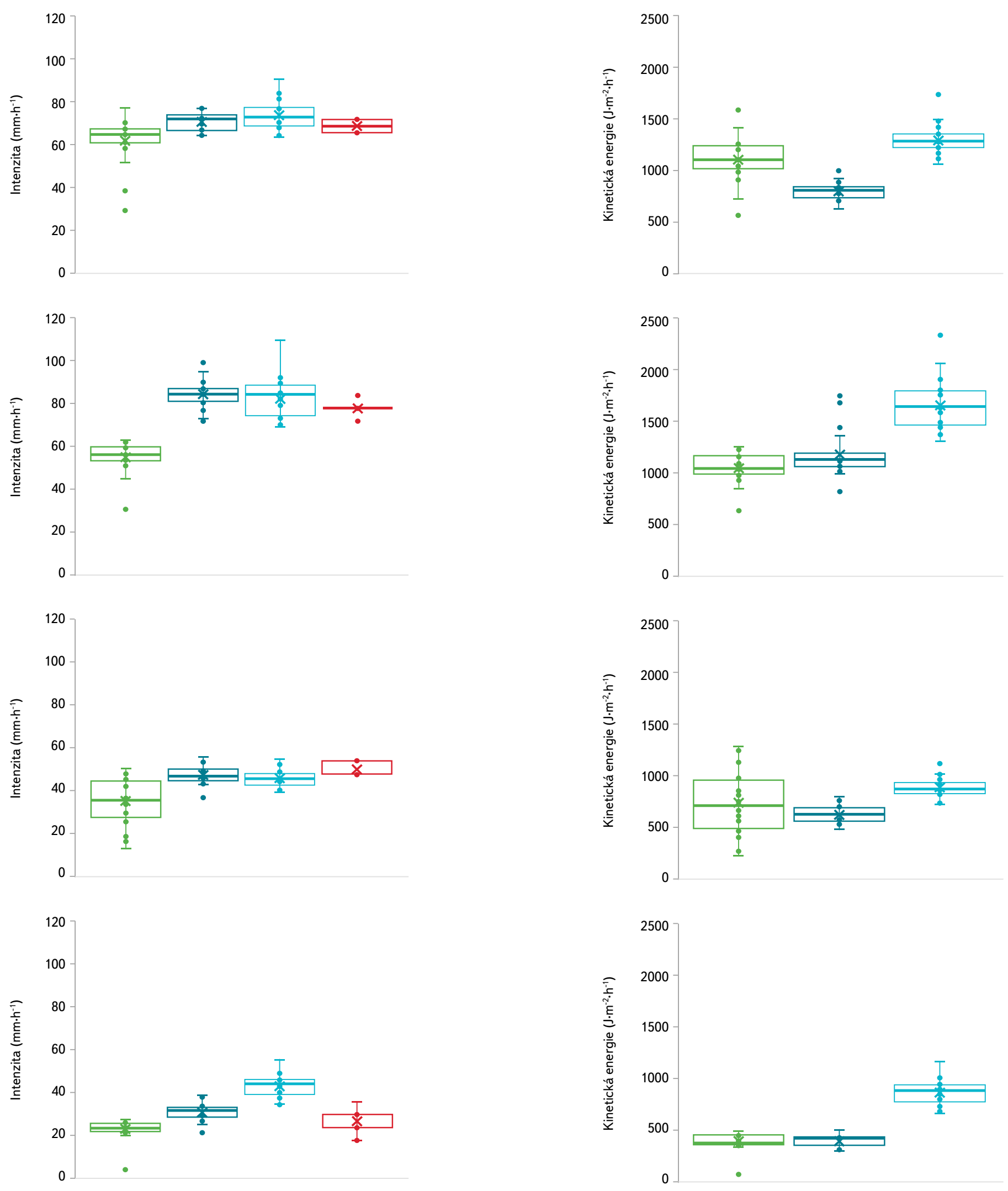

\section{LPM 1 PWS100 $\quad$ Parsivel $\quad$ Srážkomèr}

Obr. 4. Měřené hodnoty intenzity (vlevo) a kinetické energie deště (vpravo) na vybraných testovaných pozicích pod deštovým simulátorem Fig. 4. Recorded rainfall intensity (left) and rainfall kinetic energy (right) on selected positions 

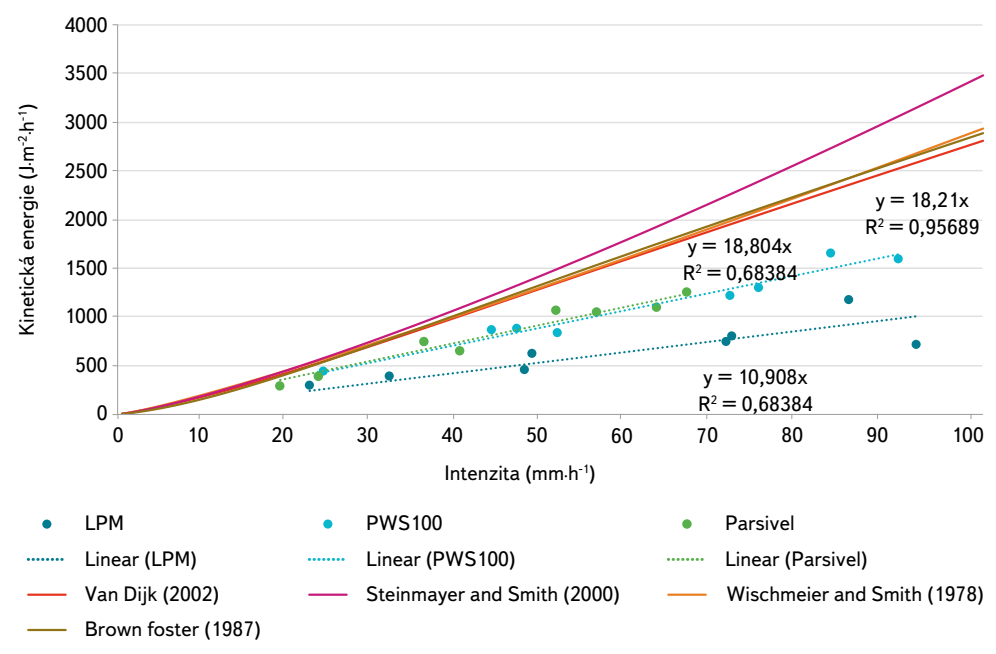

Obr. 5. Závislost měřených hodnot kinetické energie a intenzity srážky; porovnání se čtyřmi publikovanými vztahy mezi intenzitou srážky a kinetickou energií

Fig. 5. Comparison of the observed and empirical relationships between rainfall kinetic energy and intensity

LPM oproti ostatním dvěma př́strojům měří výrazně nižší kinetickou energii, jím naměřené hodnoty odpovídají v průměru 83 \% hodnot naměřených Parsivelem, resp. 59 \% hodnot naměřených PWS100. Nejvyšší hodnoty měřil PWS100. Parsivel měřil průměrně $74 \%$ hodnot naměřených pomocí PWS100 (obr. 4).

Na obr. 5 je vynesena závislost mezi intenzitou simulované srážky a měřenou kinetickou energií. Body na grafu vyjadřují průměrné měřené hodnoty zachycené třemi disdrometry. Data vykazují lineární závislost. Disdrometry Parsivel a PSW100 mají velice podobný trend se směrnicí 18,804 a 18,21 a koeficienty determinace 0,955 a 0,957. LPM vykazuje také lineární závislost s koeficientem determinace 0,683, ale v porovnání s ostatními přístroji nižší směrnicí 10,908. Oproti zbývajícím disdrometrům měří LPM výrazně nižší kinetickou energii, a to zejména při vysokých intenzitách.

Na grafu jsou vyneseny i teoretické závislosti mezi intenzitou přirozeného deště a kinetickou energií. Tyto empirické závislosti byly přejaty z literatury [21-24] a jsou běžně využivány pro odhad kinetické energie přirozeného deště i v podmínkách kontinentální Evropy (např. [25, 26]). Z porovnání plyne, že kinetická energie simulovaného deště je nižší než kinetická energie přirozených srážek. Stejná skutečnost je ještě zřetelnější při vynesení kinetické energie na milimetrový úhrn srážky (obr. 6). Zatímco kinetická energie přirozeného deště s intenzitou roste (kapky se zvětšují), v prípadě simulovaného deště je kinetická energie konstantní. Tedy s proměnlivou intenzitou simulovaného deště se nemění distribuce velikostí kapek ani jejich pádové rychlosti - což je dáno způsobem regulace intenzity deště pro kyvný deštový simulátor pomocí frekvence kyvů trysek.

\section{DISKUSE}

Cílem práce je srovnání rozdílných disdrometrů a jejich schopnost monitorovat uměle generovanou srážku. Není překvapením, že ačkoliv testování probíhalo za pečlivě kontrolovaných podmínek, výsledky měření jednotlivých přistrojů se liší. V literatuře Ize dohledat studie, které dokonce ukazují variabilitu měření i při použití stejných typů disdrometrů. Tapiador a kol. [27] monitorovali přírodní srážky pomocí 14 disdrometrů Parsivel umístěných na jedné lokalitě. Variabilita v měřených intenzitách jednotlivých disdrometrů dosahovala až $70 \%$, což, jak uvádí autoři, mohlo být dáno i prostorovou variabilitou deště, ale také systematickou odchylkou v měření jednotlivými př́stroji. Testované

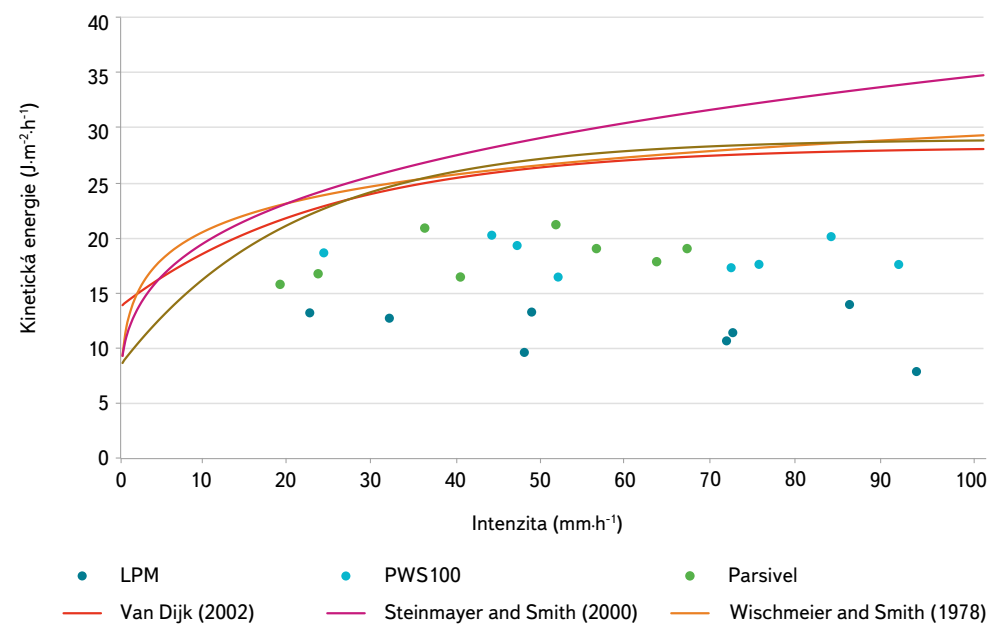

Obr. 6. Závislost kinetické energie přepočtené na milimetr srážky na intenzitě srážky; porovnání se čtyřmi publikovanými vztahy mezi intenzitou srážky a kinetickou energií Fig. 6. Comparison of the observed and empirical relationships between rainfall kinetic energy per $\mathrm{mm}$ of rainfall and rainfall intensity

disdrometry vykazují velmi dobré výsledky při monitorování intenzity umělého deště. Odchylky oproti referenčnímu srážkoměru jsou srovnatelné s měřeními v terénu, kde jsou běžné rozdíly okolo $20 \%$ [11].

Větší odchylky mezi přístroji, a tím i vyšší míra nejistoty jsou pozorovány při vyhodnocení kinetické energie deště. Zejména Thies LMP měří výrazně nižší kinetickou energii oproti ostatním prístrojům. Důvodem je pravděpodobně podhodnocená měřená pádová rychlost kapek, protože množství středních a velkých kapek je srovnatelné s ostatními disdrometry. Množství velmi malých kapek je dokonce násobně vyšší, nicméně nejmenší kapky mají na celkovou kinetickou energii minimální vliv. Měřené velké množství velmi malých kapek bylo pozorováno i v terénních aplikacích, jedno z nabízených vysvětlení spočívá v samotné konstrukci přístroje. Kapky se mohou od částí príistroje rozbíjet a odrážet před senzorem, který tak nezaznamenává pouze srážku, ale také uměle vznikající mikrokapičky [12].

Parsivel zaznamenává rychlosti kapek velmi blízké jejich terminálním pádovým rychlostem [28], měří nízký počet kapek s menším průměrem než 0,76 mm a naopak velký počet kapek větších než 2,4 mm. Stejné závěry, které mohou vést k nadhodnocení kinetické energie, přináší Angulo-Martínez a Tokay a kol. $[29,30]$.

Z testování v terénu vyplývá, že PWS100 měří mírně vyšší srážkový úhrn a dobře měrí pádové rychlosti kapek [31]. Obdobný trend byl pozorován během našeho experimentu. I během uměle generované srážky PWS100 měřil vyšší intenzitu deště. Měřené pádové rychlosti byly nižší než terminální, ale to je dáno charakteristikou simulovaného deště, při kterém maximálních rychlostí není dosaženo.

Simulovaný déšţ má znatelně nižší kinetickou energii než přírodní srážky o shodných intenzitách, k významné odchylce dochází od prahové intenzity přibližně $20 \mathrm{~mm} \cdot \mathrm{h}^{-1}$ (obr. 6). Je nutné podotknout, že tento závěr platí jen pro deštové simulátory s podobnou konstrukcí, jaká byla použita v této studii. Nicméně generování deště pomocí trysek situovaných poměrně blízko k půdnímu povrchu je v erozním výzkumu často používané $[32,33]$. Proto je velmi důležité, aby výsledky erozních experimentů prováděných s využitím deštových simulátorů byly dobře interpretovány. Nelze tvrdit, že simulovaná srážka vyvolá stejný erozní účinek jako př́rodní srážka o stejné intenzitě, nebot’ kinetická energie simulovaného deště je významně nižší. Ke stejným závěrům dospěli také Petrů a Kalibová [34], kteří zdůrazňují nutnost kalibrace vztahu mezi intenzitou a kinetickou energií pro každý simulátor (typ trysky). 


\section{ZÁVĚR}

Př́spěvek shrnuje výsledky experimentu s uměle generovaným deštěm o několika intenzitách, při kterém byly testovány a porovnávány tři nejčastěji používané disdrometry. Testované disdrometry byly poměrně spolehlivé při monitorování intenzity deště. Stanovená kinetická energie deště pomocí jednotlivých disdrometrů se však lišila. Zejména v erozních studiích nejčastěji používaný disdrometr Thies LPM měřil výrazně nižší kinetickou energii, jím naměřené hodnoty odpovídají v průměru 78 \% hodnot naměřených Parsivelem, resp. 56 \% hodnot naměřených PWS100.

Déšt generovaný pomocí tryskového simulátoru má významně nižší kinetickou energii než přirozený déšt’ o stejné intenzitě. Rozdíl v kinetické energii je významný pro srážky o intenzitě vyšší než $20 \mathrm{~mm} \cdot \mathrm{h}^{-1}$, s rostoucí intenzitou rozdíl dále roste. Toto může znamenat, že experimentálně zjištěné parametry erozních procesů nelze, bez korekce, aplikovat v simulačních modelech erozních procesů v krajině.

Tyto závěry plynou z testování konkrétních disdrometrů na jednom tryskovém deštovém simulátoru, nelze je proto zcela zobecňovat. Nicméně, konstrukce deštového simulátoru, použité trysky i disdrometry jsou v erozních laboratořích běžně použíaány, závěry jsou tak relevantní pro významnou část odborné komunity.

\section{Poděkování}

Přispěvek vznikl za podpory projektu GA17-33751L, FWF I3049-N29 a SGS 161-1611791A143.

\section{Literatura}

[1] KATHIRAVELU, G., LUCKE, T., and NICHOLS, P. Rain Drop Measurement Techniques: A Review. Water [online], 2016, vol. 8, No. 1, p. 29 [vid. 13. zárí 2018]. ISSN 2073-4441. Dostupné z: doi:10.3390/w8010029

[2] GILMORE, W.T. Comparison of rainfall energy and soil erosion parameters from a rainfall simulator and natural rain [online]. B.m., 2007 [vid. 4. prosinec 2018]. University of Missouri - Columbia. Dostupné z: doi:10.32469/10355/5101

[3] WANG, L., SHI, Z.H., WANG, J. et al. Rainfall kinetic energy controlling erosion processes and sediment sorting on steep hillslopes: A case study of clay loam soil from the Loess Plateau, China. Journal of Hydrology [online], 2014, vol. 512, p. 168-176 [vid. 16. červenec 2019]. ISSN 0022-1694. Dostupné z: doi:10.1016/J.JHYDROL.2014.02.066

[4] MOUSSOUNI, A., MOUZAI, L., and BOUHADEF, M. The Effect of Raindrop Kinetic Energy on Soil Erodibility [online], 2015 [vid. 16. červenec 2019]. Dostupné z: doi:10.5281/ZENOD0.1337717

[5] MAZON, J. and VIÑAS, M. A low-cost experiment for determining raindrop size distribution. Weather [online], 2013, vol. 68, No. 2, p. 49-52 [vid. 13. záŕi 2018]. ISSN 00431656. Dostupné z: doi:10.1002/ wea.2064

[6] DE LIMA, J.L.M.P. SILVA, V.P. DE LIMA, M.IP. et al. Revisiting simple methods to estimate drop size distributions: a novel approach based on infrared thermography. Journal of Hydrology and Hydromechanics [online], 2015, vol. 63, No. 3, p. 220-227 [vid. 13. záŕí 2018]. ISSN 0042-790X. Dostupné z: doi:10.1515/johh-2015-0025

[7] LIU, X.C., GAO, T.C., and LIUM, L. A comparison of rainfall measurements from multiple instruments. Atmospheric Measurement Techniques [online], 2013, vol. 6, No. 7, p. 1585-1595 [vid. 4. prosinec 2018]. ISSN 1867-8548. Dostupné z: doi:10.5194/amt-6-1585-2013

[8] FIŠER, O., SCHÖNHUBER, M., and PEŠICE, P. First Results of DSD Measurement by Videodistrometer in the Czech Republic in 1998-1999. Studia Geophysica et Geodaetica [online], 2002, vol. 46, No. 3, p. 485-505. ISSN 1573-1626. Dostupné z: doi:10.1023/A:1019591002211

[9] SARKAR, T., DAS, S., and MAITRA, A. Assessment of different raindrop size measuring techniques: Inter-comparison of Doppler radar, impact and optical disdrometer. Atmospheric Research [online], 2015, vol. 160, p. 15-27 [vid. 13. září 2018]. ISSN 0169-8095. Dostupné z: doi:10.1016/J.ATMOSRES.2015.03.001

[10] NAKAYA, K. and TOYODA, Y. Comparison of the compact Dopplar radar rain gauge and optical disdrometer. Journal of Agricultural Meteorology [online], 2011, p. 67.3.12 [vid. 13. zárí 2018]. ISSN 00218588. Dostupné z: doi:10.2480/agrmet.67.3.12

[11] LANZINGER, E., THEEL, M., and WINDOLPH, H. Rainfall Amount and Intensity Measured by the Thies Laser Precipitation Monitor. In: TECO-2006, Geneva, Switzerland, 2006, p. 4-6.

[12] ANGULO-MARTÍNEZ, M., BEGUERÍA, S., LATORRE, B. et al. Comparison of precipitation measurements by OTT Parsivel2 and Thies LPM optical disdrometers. Hydrology and Earth System Sciences [online]. 2018, vol. 22, No. 5, p. 2811-2837 [vid. 13. záŕí 2018]. ISSN 1607-7938. Dostupné z: doi:10.5194/hess-22-2811-2018
[13] BLOEMINK, H.I. and LANZINGER, E. Precipitation type from the Thies disdrometer. In: Proceedings of the WMO Technical Conference on Instruments and Methods of Observation, 2005, p. 4-7.

[14] ANGULO-MARTÍNEZ, M., BEGUERÍA, S., and KYSELÝ, J. Use of disdrometer data to evaluate the relationship of rainfall kinetic energy and intensity (KE-I). Science of the Total Environment [online]. 2016, vol. 568, p. 83-94. ISSN 18791026. Dostupné z: doi:10.1016/j.scitotenv.2016.05.223

[15] FRASSON, R.P. de M., DA CUNHA, L.K., and KRAJEWSKI, W.F. Assessment of the Thies optical disdrometer performance. Atmospheric Research [online], 2011, vol. 101, No. 1-2, p. 237-255 [vid. 13. září 2018]. ISSN 0169-8095. Dostupné z: doi:10.1016/J.ATMOSRES.2011.02.014

[16] JOHANNSEN, L., ZAMBON, N., STRAUSS, P. et al. Comparison of three types of laser optical disdrometers under natural rainfall conditions. Hydrological Sciences Journal (podáno), 2019.

[17] ISERLOH, T., FISTER, W., SEEGER, M. et al. A small portable rainfall simulator for reproducible experiments on soil erosion. Soil and Tillage Research [online], 2012, vol. 124, p. 131-137. ISSN 01671987. Dostupné z: doi:10.1016/j.still.2012.05.016

[18] KAVKA, P. Developing of the laboratory rainfall simulator for testing the technical soil surface protection measures and droplets impact. In: Proceedings of the XVII ECSMGE-2019, 2019.

[19] LABURDA, T. a kol. Využití laboratorního deštového simulátoru ČVUT v dlouholetém výzkumu eroze půdy. In: Sborník príspěvků ze semináre Adolfa Patery 2014 na téma "Extrémní hydrologické jevy vpovodich" [online], 2014, s. 97-104. Dostupné z: doi:978-80-02-02574-0

[20] BRINGI, V.N., CHANDRASEKAR, V., HUBBERT, J. et al. Raindrop Size Distribution in Different Climatic Regimes from Disdrometer and Dual-Polarized Radar Analysis. Journal of the Atmospheric Sciences [online], 2003, vol. 60, No. 2, p. 354-365. ISSN 0022-4928. Dostupné z: doi:10.1175/1520-0469(2003)060<0354:RSDIDC>2.0.CO;2

[21] STEINER, M. and SMITH, J.A. Reflectivity, Rain Rate, and Kinetic Energy Flux Relationships Based on Raindrop Spectra. Journal of Applied Meteorology [online], 2000, vol. 39, No. 11, p. 1923-1940 [vid. 10. červenec 2019]. ISSN 0894-8763. Dostupné z: doi:10.1175/1520-0450(2000)039<1923:RRRAKE $>2.0 . C O ; 2$ [22] VAN DIJK, A.I.J., BRUIJNZEEL, L., and ROSEWELL, C. Rainfall intensity-kinetic energy relationships: a critical literature appraisal. Journal of Hydrology [online], 2002, vol. 261, No. 1-4, p. 1-23 [vid. 10. červenec 2019]. ISSN 0022-1694. Dostupné z: doi:10.1016/S0022-1694(02)00020-3

[23] BROWN, L.C. and FOSTER, G.R. Storm erosivity using idealized intensity distributions. Transactions of the ASAE, American Society of Agricultural Engineers [online], 1987, vol. 30, No. 2, p. 379-386 [vid. 10. červenec 2019]. Dostupné z: https://eurekamag.com/research/001/690/001690998.php

[24] WISCHMEIER, W.H. and SMITH, D.D. Predicting rainfall erosion losses: a guide to conservation planning [USA]. United States. Dept. of Agriculture. Agriculture handbook (USA) [online], 1978 [vid. 14. listopad 2018]. Dostupné z: http://agris.fao.org/agris-search/search.do?recordID=US7904839

[25] ZUMR, D., JEŘÁBEK, J., KLÍPA, V. et al. Estimates of Tillage and Rainfall Effects on Unsaturated Hydraulic Conductivity in a Small Central European Agricultural Catchment. Water [online], 2019, vol. 11, No. 4, p. 740. ISSN 2073-4441. Dostupné z: doi:10.3390/w11040740

[26] VERSTRAETEN, G., POESEN, J., DEMARÉE, G. et al. Long-term (105 years) variability in rain erosivity as derived from 10-min rainfall depth data for Ukkel (Brussels, Belgium): Implications for assessing soil erosion rates. Journal of Geophysical Research [online]. 2006, vol. 111, No. D22, p. D22109. ISSN 0148-0227. Dostupné z: doi:10.1029/2006JD007169

[27] TAPIADOR, F.J., CHECA, R., and DE CASTRO, M. An experiment to measure the spatial variability of rain drop size distribution using sixteen laser disdrometers. Geophysical Research Letters [online], 2010, vol. 37, No. 16 [vid. 13. záři 2018]. ISSN 00948276. Dostupné z: doi:10.1029/2010GL044120

[28] FOOTE, G.B., DU TOIT, P.S., FOOTE, G.B. et al. Terminal Velocity of Raindrops Aloft. Journal of Applied Meteorology [online], 1969, vol. 8, No. 2, p. 249-253 [vid. 10. červen 2019]. ISSN 0021-8952. Dostupné z: doi:10.1175/1520-0450(1969)008<0249:TVORA >2.0.CO;2

[29] ANGULO-MARTINEZ, M. and BARROS, A. Measurement uncertainty in rainfall kinetic energy and intensity relationships for soil erosion studies: An evaluation using PARSIVEL disdrometers in the Southern Appalachian Mountains. Geomorphology [online], 2015, vol. 228, p. 28-40. Dostupné z: doi:10.1016/j.geomorph.2014.07.036

[30] TOKAY, A., PETERSEN, W.A., GATLIN, P. et al. Comparison of Raindrop Size Distribution Measurements by Collocated Disdrometers. Journal of Atmospheric and Oceanic Technology [online], 2013, vol. 30, No. 8, p. 1672-1690 [vid. 4. prosinec 2018]. ISSN 0739-0572. Dostupné z: doi:10.1175/ JTECH-D-12-00163.1

[31] MONTERO-MARTÍNEZ, G., TORRES-PÉREZ, E.F., and GARCÍA-GARCÍA, F. A comparison of two optical precipitation sensors with different operating principles: The PWS100 and the OAP-2DP. Atmospheric Research [online]. 2016, vol. 178-179, p. 550-558 [vid. 12. záŕí 2018]. ISSN 0169-8095. Dostupné z: doi:10.1016/J.ATMOSRES.2016.05.007

[32] DOSTÁL, T., STRAUSS, P., SCHINDEWOLF, M. et al. Comparison of different types of medium scale field rainfall simulators. In: EGU General Assembly 2015, held 12-17 April, 2015 in Vienna, Austria, 2015.

[33] POLYAKOV, V., STONE, J., HOLIFIELD COLLINS, C. et al. Rainfall simulation experiments in the southwestern USA using the Walnut Gulch Rainfall Simulator. Earth System Science Data [online], 2018 vol. 10, No. 1, p. 19-26. Dostupné z: doi:10.5194/essd-10-19-2018

[34] PETRŮ, J. and KALIBOVÁ, J. Measurement and computation of kinetic energy of simulated rainfall in comparison with natural rainfall. Soil and Water Research [online], 2018, vol. 13, No. 4, p. 226-233. Dostupné z: doi:10.17221/218/2016-SWR 
Autoři

Ing. Martin Neumann ${ }^{1}$

martin.neumann@fsv.cvut.cz

Ing. David Zumr, Ph.D.

冈david.zumr@fsv.cvut.cz

Ing. Petr Kavka, Ph.D.'

凶petr.kavka@fsv.cvut.cz

Ing. Tomáš Laburda'

凶tomas.laburda@fsv.cvut.cz

MSc. Lisbeth Lolk Johannsen²

凶lisbeth.johannsen@boku.ac.at

Mag. Nives Zambon ${ }^{2}$

凶nives.balenovic@boku.ac.at

doc. Dr. Ing. Tomáš Dostál ${ }^{1}$

凶dostal@fsv.cvut.cz

Dipl.-Ing. Dr.nat.techn. Peter Strauss ${ }^{3}$

凶peter.strauss@baw.at

Ao.Univ.Prof. Dipl.-Ing. Dr.nat.techn. Andreas Klik ${ }^{2}$ 凶andreas.klik@boku.ac.at

'České vysoké učení technické v Praze, Fakulta stavební

${ }^{2}$ University of Natural Resources and Life Sciences,

Institute for Soil Physics and Rural Water Management, Rakousko

${ }^{3}$ Federal Agency for Water Management,

Institute for Land \& Water Management Research, Rakousko

Příspěvek prošel lektorským řízením.

\section{CHARACTERIZATION OF AN ARTIFI- \\ CIALLY GENERATED RAINFALL USED FOR A SOIL EROSION RESEARCH}

\section{NEUMANN, M.'; ZUMR, D.'; KAVKA, P.'; LABURDA, T.'; JOHANNSEN, L.L..; ZAMBON, N. ${ }^{2}$; DOSTAL, T. ${ }^{1}$; STRAUSS, P. ${ }^{3}$; KLIK, A. ${ }^{2}$}

${ }^{1}$ Czech Technical University in Prague, Faculty of Civil Engineering

${ }^{2}$ University of Natural Resources and Life Sciences,

Institute for Soil Physics and Rural Water Management, Austria

${ }^{3}$ Federal Agency for Water Management,

Institute for Land \& Water Management Research, Austria

Keywords: disdrometer - rainfall kinetic energy -

rainfall intensity - rainfall simulator - soil erosion

A rainfall simulator is a common laboratory tool for soil erosion research. Typical objective of the rainfall experiments is the evaluation of various factors on soil erosion processes, such as the effect of rainfall intensity, rainfall duration, soil characteristics, soil management, crop residues on the soil surface, plot's slope and length. The results of the experiments are then upscaled to estimate the erosion processes in the landscape or they serve as the calibration data for the simulation models. Due to the fact that the soil erosion is initiated by the rainfall, it is crucial to keep the simulated rainfall characteristics as close as possible to the natural rainfall. Rainfall intensity is usually easy to control, but the rainfall kinetic energy is the driving force of the initial stage of the erosion. The aim of this study is to evaluate the simulated rainfall characteristics, incl. its drop size distribution and kinetic energy, and compare the simulated rainfall to the natural rainfall. Within a study we also compared three common disdrometers and we show limitation of the disdrometers to monitor the artificially generated rainfall.

The experiments were done with a use of nozzle type rainfall simulator. The rainfall characteristics were monitored by disdrometers LPM (Thies Clima), Parsivel (OTT) and PWS100 (Campbell Sci.), standard raingauge was used as a reference measurement for the intensity monitoring. The intensity, recorded with the disdrometers, was very similar to the rain gauge. In the average it measured 106\% (LPM), 79\% (Parsivel) and 116\% (PWS100) of rain gauge value. There was a large difference between the disdrometers in the measured kinetic energy values. LPM significantly underestimated the kinetic energy compared to the other disdrometers it measured 83\% of Parsivel value and 59\% of PWS100 value. The highest values were measured with the PWS100. The key conclusion is, that a simulated rainfall with the intensity above $20 \mathrm{~mm} \cdot \mathrm{h}^{-1}$, has significantly lower kinetic energy, compared to a natural rainfall with same intensity. 